\title{
IMPLEMENTASI PROGRAM SERTIFIKASI GURU DALAM MENINGKATKAN PROFESIONALISME GURU (STUDI PADA GURU PPKn DI SMP NEGERI 2 KUTA UTARA KABUPATEN BADUNG)
}

\author{
I Gede Sujana \\ Fakultas Keguruan dan Ilmu Pendidikan, Universitas Dwijendra \\ e-mail: (dalungsujana@gmail.com)
}

\begin{abstract}
Abstrak
Tujuan penelitian ini adalah : (1) mengetahui bagaimana implementasi program sertifikasi guru pada guru PPKn di SMP Negeri 2 Kuta Utara, Kabupaten Badung; (2) mengidentifikasi kendala yang dihadapi guru PPKn dalam meningkatkan profesionalisme guru dengan adanya implementasi program sertifikasi guru di SMP Negeri 2 Kuta Utara Kabupaten Badung; dan (3) menganalisis solusi terhadap permasalahan yang di hadapi guru PPKn sehubungan dengan profesionalisme guru di SMP Negeri 2 Kuta Utara Kabupaten Badung. Penelitian ini dilakukan di SMP Negeri 2 Kuta Utara Kabupaten Badung. Subjek penelitian ini adalah para guru PPKn yang sudah bersertifikasi yang berjumlah 5 (lima) orang. Pengumpulan data menggunakan teknik observasi, wawancara, pencatatan dokumen, dan data dianalisis secara deskriptif kualitatif. Hasil penelitian menunjukkan : (1) implementasi program sertifikasi guru di SMP Negeri 2 Kuta Utara Kabupaten Badung sudah berjalan dengan baik dimana sertifikasi berpengaruh terhadap sikap profesionalisme guru PPKn yang tercermin dari adanya peningkatan kinerja guru; (2) kendala yang dihadapi guru PPKn di SMP Negeri 2 Kuta Utara Kabupaten Badung yaitu penyediaan fasilitas pendidikan yang masih terbatas seperti LCD; masalah terhadap administrasi penilaian siswa sebagai implikasi dari penerapan kurikulum 2013. (3) analisis solusi terhadap kendala yang terjadi yaitu : sekolah dapat mengupayakan pemenuhan kebutuhan fasilitas pendidikan yang memadai dan relevan dengan pembelajaran terkini secara bertahap melalui perencanaan, pengeloalaan dan pemanfaatan dana yang tersedia, baik dari swadaya atau subsidi pemerintah; penyediaan tenaga TI professional untuk memberikan pelatihan guna membantu guru yang masih kesulitan mengerjakan administrasi penilaian siswa karena kendala pengoprasian ICT; perlunya pengaturan intensitas pertemuan MGMP PPKn secara rutin, guna membangun komunikasi yang efektif antar guru mata pelajaran PPKn.
\end{abstract}

Kata-kata kunci: Guru PPKn, Program Sertifikasi Guru, Profesionalisme Guru

\begin{abstract}
The aims of this study are: (1) to find out how the implementation of the teacher certification program to the Pancasila and Civics Education teachers at SMP Negeri 2 Kuta North Badung Regency; (2) to identify the constraints faced by Pancasila and Civic Education teachers toward teacher professionalism with the implementation of teacher certification program at SMP Negeri 2 Kuta North Badung Regency; and (3) analyze the solutions to the problems that the Pancasila and Civics Education teachers often found in the relation of teachers professionalism at SMP Negeri 2 North Kuta Badung Regency. This research was conducted at SMP Negeri 2 Kuta North Badung Regency. The subjects of this research were 5 Pancasila and Civics Education teachers who are already certified. This study used observation, interview, and record-keeping when collecting the data, and then the data were analyzed descriptively. This study found that; (1) the implementation of the teacher certification program at SMP Negeri 2 Kuta North Badung Regency has been done well and the certification is affecting the Pancasila and Civics Education teacher professionalism which reflected in the improvement of teacher performance; (2) the problems that Pancasila and Civics Education teacher at SMP Negeri 2 Kuta North Badung Regency often faced is the educational facilities supplies that are still limited such as the LCD and the administration of student assessments problems as the affect of the implementation of the 2013 curriculum. (3) The Solution to problems that occur are: the school should be able to plan and manage the school budget either from governmental or government subsidies for gradually fulfilling the supply of educational facilities which relevant with the recent learning program; The provision of professionals IT to provide training for helping the teachers who are still working on the administration of student assessments difficulties because of the application of ICT program; the management of regular meeting of the Pancasila and
\end{abstract}


Civics Education MGMPs, in order to establish effective communication among teachers of Pancasila and Civics Education.

Keywords: Pancaila and Civics Eduvation Teacher, Teacher Certification Program, Teacher Professionalism

\section{PENDAHULUAN}

Undang-Undang Dasar Republik

Indonesia Tahun 1945 mengamanatkan Pemerintah RI untuk memajukan kesejahteraan umum dan mencerdaskan kehidupan bangsa dan juga mengamanatkan untuk mengusahakan dan menyelenggarakan satu sistem pendidikan nasional yang bertujuan meningkatkan keimanan dan ketakwaan kepada Tuhan yang Maha Esa serta akhlak mulia dalam rangka mencerdaskan kehidupan bangsa dan membentuk watak serta peradaban bangsa yang bermartabat. Untuk mengemban amanat tersebut ditetapkanlah Undang-Undang RI Nomor 20 Tahun 2003 tentang Sistem Pendidikan Nasional untuk manjamin pemerataan kesempatan pendidikan, meningkatkan mutu dan relevansi pendidikan serta efisiensi menajeman pendidikan dalam rangka menghadapi tuntutan perubahan kehidupan lokal, nasional dan global.

Sebagai upaya dalam peningkatan mutu pendidikan tersebut maka lahirlah Peraturan Pemerintah RI Nomor 19 Tahun 2006 tentang Standar Nasional Pendidikan yang menetapkan 8 (delapan) Standar Nasional Pendidikan yang menjadi acuan dalam penyelenggaraan serta keberhasilan pendidikan nasional. Salah satu dari standar tersebut adalah standar pendidik dan tenaga kependidikan. Dalam Peraturan Pemerintah tersebut berkenaan dengan standar pendidik dan tenaga kependidikan dinyatakan bahwa pendidik harus memiliki kualifikasi akademik dan kompetensi. Kualifikasi akademik dan kompetensi yang dimaksudkan oleh Peraturan Pemerintah tersebut melahirkan Peraturan Menteri Pendidikan Nasional RI Nomor 16 Tahun
2007 tentang Standar Kualifikasi Akademik dan Kompetensi Guru. Standar kualifikasi akademik dan kompetensi guru ini lah yang menjadi dasar bagi pelaksanaan program sertifikasi guru yang melahirkan Peraturan Manteri Pendidikan Nasional Republik Indonesia Tentang Sertifikasi bagi Guru dalam Jabatan yang dimulai dari permendiknas Nomor 18 Tahun 2007 pada tanggal 4 Mei 2007. Kebijakan Sertfikasi Guru merupakan salah satu upaya pemerintah untuk memperbaiki dan meningkatkan kualitas pendidikan, khususnya untuk meningkatkan performa atau kompetensi guru di seluruh wilayah Indonesia. Dengan disahkannya Undang-Undang Nomor 14 Tahun 2005 tentang Guru dan Dosen pada bulan Desember 2005. Sertifikasi guru adalah proses pemberian sertifikat pendidik kepada guru yang telah memenuhi standar kualifikasi akademik dan kompetensi dengan mengacu pada Undang Undang Republik Indonesia Nomor 14 Tahun 2005 tentang Guru dan Dosen, Peraturan Pemerintah Nomor 19 Tahun 2005 tentang Standar Nasional Pendidikan, Peraturan Menteri Pendidikan Nasional Nomor 16 Tahun 2007 tentang Standar Kualifikasi Akademik dan Kompetensi Guru, dan Peraturan Menteri Pendidikan Nasional Nomor 18 Tahun 2007 tentang Sertifikasi Guru dalam Jabatan. (Djaali, 2009)

Sampai saat ini sambutan para guru terhadap kebijakan pemerintah ini memang luar biasa. Para guru sangat antusias untuk mengikuti serangkaian kegiatan seleksi untuk dapat lulus program ini. Namun nyatanya, masih terdapat ketidak seragaman tujuan sertifikasi pendidik, baik dalam payung hukum, versi penyelenggara dan 
penerapanya di lapangan, sehingga mengakibatkan terjadinya berbagai kerancuan dalam implementasinya. Salah satu permasalahan yang terjadi adalah terkait dengan beban mengajar yang harus dijalankan.

Sebenarnya banyak hal yang diungkapkan dalam Undang-Undang Nomor 14 Tahun 2005 tentang Guru dan Dosen, salah satunya adalah pasal 35 ayat 2 yang menyatakan bahwa beban mengajar guru adalah minimal 24 jam tatap muka perminggu dan maksimal 40 jam tatap muka perminggu. Pada ayat 3 selanjutnya disebutkan bahwa ketentuan lebih lanjut mengenai beban kerja guru diatur lebih lanjut dalam Peraturan Pemerintah. Guna menindaklanjuti hal tersebut, maka diterbitkanlah Peraturan Pemerintah nomor 74 tahun 2008 tentang Guru, pada salah satu pasalnya yaitu pasal 52 ayat 2 menegaskan kembali UU nomor 14 tahun 2005 pasal 35 ayat 2 yang mewajibkan beban kerja guru minimal 24 jam tatap muka perminggu dan maksimal 40 jam tatap muka perminggu. Pasal 62 ayat 2 menyebutkan bahwa guru yang tidak bisa memenuhi kewajiban beban mengajar minimal 24 jam tatap muka perminggu dihilangkan haknya untuk memperoleh tunjangan profesi, tunjangan fungsional, subsidi tunjangan fungsional dan maslahat tambahan.

Sertifikasi guru merupakan salah satu isu sentral dalam dunia pendidikan di mana guru yang telah lulus ujian kompetensi guru dan telah mengukuti diklat sertifikasi guru berhak mendapat tunjangan sertifikasi guru sebesar 1 kali lipat gaji pokok setiap bulannya. Tidak semua guru bisa lulus ujian kompetensi guru karena perbedaan kualitas SDM guru. Tidak semua guru yang telah lulus ujian kompetensi guru bisa mengikuti diklat sertifikasi guru dengan baik dan berhasil lulus diklat. Dan ternyata tidak semua guru yang telah lulus sertifikasi guru bisa mendapatkan tunjangan sertifikasi guru. Kewajiban 24 jam mengajar perminggu tingkat pemenuhannya memiliki banyak parameter, di antaranya yang utama adalah jumlah murid dan jumlah guru mata pelajaran sejenis. Bila jumlah murid mencukupi maka kewajiban beban mengajar minimal 24 jam perminggu bukanlah masalah dengan catatan perbandingan murid dan perbandingan jumlah guru mata pelajaran sejenis memiliki komposisi yang memungkinkan untuk membagi jam pelajaran sehingga kewajiban beban mengajar minimal 24 jam perminggu bisa terpenuhi. Akan tetapi masalah muncul bila jumlah murid tidak terpenuhi akibat fluktuasi jumlah murid pertahun yang tidak stabil. Sesuai dengan hal tersebut, maka penulis tertarik untuk melakukan sebuah penelitian yang mengkaji tentang implementasi program sertifikasi guru dalam meningkatkan profesionalisme guru (studi pada guru Pendidikan Pancasila dan Kewarganegaraan di SMP Negeri 2 Kuta Utara Kabupaten Badung).

Berdasarkan uraian di atas, maka ditarik beberapa masalah penelitian yaitu sebagai berikut: 1). Bagaimana implementasi program sertifikasi guru pada guru PPKn di SMP Negeri 2 Kuta Utara Kabupaten Badung?, 2). Apa kendala yang dihadapi guru PPKn dalam meningkatkan profesionalisme guru dengan adanya implementasi program sertifikasi guru di SMP Negeri 2 Kuta Utara Kabupaten Badung?, 3). dan Bagaimana solusi terhadap permasalahan yang di hadapi guru PPKn sehubungan dengan profesionalisme guru di SMP Negeri 2 Kuta Utara Kabupaten Badung?.

Sehingga tujuan yang dicapai dalam penelitian ini yakni untuk: mengetahui implementasi program sertifikasi guru pada guru PPKn di SMP Negeri 2 Kuta Utara Kabupaten Badung, 
mengidentifikasi kendala yang dihadapi guru PPKn dalam meningkatkan profesionalisme guru dengan adanya implementasi program sertifikasi guru di SMP Negeri 2 Kuta Utara Kabupaten Badung, dan menganalisis solusi terhadap permasalahan yang di hadapi guru PPKn sehubungan dengan profesionalisme guru di SMP Negeri 2 Kuta Utara Kabupaten Badung.

\section{METODE PENELITIAN}

2.1 Jenis Penelitian

Jenis penelitian ini adalah penelitian lapangan (field research). Penelitian ini bertujuan untuk mendeskripsikan implementasi program sertifikasi guru dalam meningkatkan profesionalisme guru di SMP Negeri 2 Kuta Utara Kabupaten Badung sehingga menghasilkan informasi yang terorganisir dengan baik dan data yang lengkap. Metode yang digunakan dalam penelitian ini adalah metode penelitian kualitatif (qualitative research) yaitu suatu penelitian yang ditujukan untuk mendeskripsikan dan menganalisis suatu fenomena, peristiwa, aktivitas sosial, sikap, persepsi, dan pemikiran orang secara individual maupun kelompok. Selanjutnya dari hasil pengolahan ini disajikan dengan analisis deskriptif, disusun secara sistematis (Santika dan Kartika, 2019:62).

\subsection{Lokasi Penelitian}

Lokasi penetian merupakan tempat yang dijadikan pusat untuk melaksanakan penelitian. Adapun lokasi penelitian yang dipilih adalah SMP Negeri 2 Kuta Utara Kabupaten Badung. Penulis mengambil data di SMP Negeri 2 Kuta Utara Kabupaten Badung karena penulis menemukan permasalahan terkait dengan implementasi program sertifikasi guru yang menyangkut aspek pelaksanaan kegiatan proses pembelajaran sehingga menarik untuk diteliti dan dicarikan solusi.

\subsection{Subyek Penelitian}

Penentuan subjek dalam penelitian ini adalah dengan menggunakan teknik Purposive (Purposive Sampling) karena berdasarkan atas pertimbangan tujuan penelitian bahwa informan yang dibutuhkan untuk memberikan informasi yang dibutuhkan sudah jelas. Sedangkan penentuan informan pendukung dilakukan secara acak (random sampling). Dalam hal ini yang menjadi subjek penelitian yaitu para guru Pendidikan Kewarganegaraan (PPKn) yang sudah bersertifikasi sebanyak 5 (lima) orang, sedangkan informan pendukung terdiri dari Kepala Sekolah, dan rekan sesama guru yang juga berasal dari lingkungan yang sama yakni di SMP Negeri 2 Kuta Utara Kabupaten Badung.

\subsection{Teknik Pengumpulan Data}

\subsubsection{Observasi}

Teknik observsasi biasa diartikan sebagai pengamatan dan pencatatan dengan sistematik fenomena-fenomena yang diselidiki dengan melihat langsung kelapangan, terhadap objek yang diteliti. Melalui metode observasi ini, peneliti akan mengamati terkait masalah yang diteliti dalam jangka waktu tertentu terkai dengan kebijakan program sertifikasi guru dan profesionalisme guru di SMP Negeri 2 Kuta Utara Kabupaten Badung.

\subsubsection{Wawancara}

Wawancara atau Interview adalah sebuah dialog yang dilakukkan oleh pewawancara (interviewer) untuk memperoleh informasi dari terwawancara (Suharsimi, 2007). Metode wawancara dilakukam kepada subyek penelitian yaitu guru PPKn yang telah bersertifikasi selaku informan untuk 
mendapatkan informasi terkait kebijakan program sertifikasi guru dan profesionalisme guru dengan menggunakan pedoman wawancara yang telah disiapkan yang selanjutnya informasi tersebut dicatat secara sistematis.

\subsubsection{Dokumentasi}

Teknik dokumentasi adalah mencari data mengenai hal-hal atau variable yang berupa catatan, transkip, buku, surat kabar, majalah, agenda, dan sebagainya (Suharsimi, 2007). Dalam penelitian ini, peneliti mengambil data seperti profil sekolah, biografi subyek, rekaman, gambar-gambar pelaksanaan kegiatan belajar mengajar, dan lain-lain.

2.5 Metode Analisis Data

Analisis data menurut Moleong (2006) adalah "proses mengatur urut data". Adapun teknik yang digunakan dalam penulisan ini adalah Analisis deskriptif kualitatif. Deskriptif kualitatif yaitu penelitian yang dilakukan untuk menggambarkan suatu variabel secara mandiri, baik satu variabel atau lebih tanpa membuat perbandingan atau menghubungkan variabel dengan variabel lainnya (Narbuko, 2005:44). Secara spesifik tahap pengumpulan data dan analisis data yang digunakan dalam penelitian ini adalah meliputi tahapan-tahapan yaitu : (1) pengumpulan data; (2) reduksi data; (3) penyajian data; (4) penarikan kesimpulan atau verifikasi. (Miles dan Huberman, 2000).

\section{HASIL DAN PEMBAHASAN}

3.1 Hasil Penelitian

\subsubsection{Gambaran Umum SMP Negeri 2 Kuta Utara Kabupaten Badung}

SMP Negeri 2 Kuta Utara Kabupaten Badung secara resmi beroperasi pada tahun 2011. Walaupun usia sekolah masih relative muda, namun sudah mampu melahirkan sederet prestasi baik di tingkat kabupaten, provinsi maupun tingkat nasional. Hal ini tidak luput dari kerja keras dan kerja sama civitas SMP Negeri 2 Kuta Utara.Sampai saat ini, jumlah guru yang dipekerjakan di SMP Negeri 2 Kuta Utara sebanyak 73 orang, tenaga kependidikan 28 orang, dan jumlah siswa 1393 orang yang terdiri dari laki-laki 723 orang dan perempuan 670 orang.

Secara Geografis SMP Negeri 2 Kuta Utara berlokasi di Jl. Made Bulet Wilayah Banjar Tegeh, Desa Dalung, Kecamatan Kuta Utara Kabupaten Badung. Lokasi SMP Negeri 2 Kuta Utara merupakan wilayah yang sangat srategis, yakni berada di kawasan perdesaan yang padat penduduk. Jaraknya kurang lebih $1,73 \mathrm{~km}$ dari pusat Pemerintahan Kabupaten Badung. SMP Negeri 2 Kuta Utara Kabupaten Badung berdiri di atas lahan dengan luas $9000 \mathrm{~m} 2$ yang dibatasi oleh:
1. Sebelah utara
: Perumahan Penduduk
2. Sebelah timur
Jalan Perumahan Penduduk
3. Sebelah selatan
: Perkebunan
4. Sebelah barat
: Perumahan Penduduk.

Visi Misi SMP Negeri 2 Kuta Utara Kabupaten Badung

Visi Sekolah: Berprestasi, Berbudaya, Berkarakter dan Berlandaskan Lingkungan.

Misi Sekolah:

1. Melaksanakan kegiatan pembelajaran yang interaktif, inspiratif, menyenangkan, menantang, memotivasi, kontekstual dan kolaboratif yang berbasis Teknologi informasi;

2. Pengadaan dan/atau melengkapi sarana dan prasarana sekolah;

3. Meningkatkan/mengembangkan profesionalisme pendidik dan tenaga kependidikan; 
4. Melaksanakan bimbingan kelompok belajar secara optimal;

5. Meningkatkan pembinaan kegiatan pengembangan diri;

6. Melaksanakan kegiatan keagamaan secara berkala dan berkesinambungan

7. Melaksanakan kegiatan kebersihan dan pelestarian lingkungan;

8. Meningkatkan implementasi PPKn, Pendidikan Agama dan Budi Pekerti;

9. Mengintegrasikan Pendidikan Karakter Bangsa secara terpadu dalam kegiatan kurikuler dan kegiatan ekstrakurikuler/pengembangan diri.

Penataan Lingkungan Sekolah

Penataan lingkungan fisik terutama bangunan yang ada di SMP Negeri 2 Kuta Utara sudah ditata dengan sangat baik dan rapi sesuai dengan fungsinya masing-masing. Selain penataan yang baik secara fisik, fasilitas yang dimiliki SMP Negeri 2 Kuta Utara Kabupaten Badung juga cukup lengkap dalam mendukung proses pembelajaran. Beberapa fasilitas yang ada berupa Laboratorium, jaringan internet (WIFI), mesin fotocopy, kipas angin, AC, speaker di masing-masing kelas dan lain sebagainya. Penataan lingkungan sekolah SMP Negeri 2 Kuta Utara Kabupaten Badung mengikuti konsep Tri Hita Karana yaitu Parahyangan, Pawongan, Palemahan, begitu juga konsep Tri Mandala yaitu Utama Mandala, Madya Mandala, dan Nista Mandala.

\subsection{Pembahasan}

\subsubsection{Implementasi Program Sertifikasi Guru Pada}

Guru Pendidikan Pancasila dan Kewarganegaraan di SMP Negeri 2 Kuta Utara Kabupaten Badung

Berdasarkan hasil wawancara dengan guruguru Pendidikan Pancasila dan Kewarganegaraan di
SMP Negeri 2 Kuta Utara Kabupaten Badung, yakni dengan Ibu Ni Ketut Sri Arini, S.Pd., Ibu Ni Made Rai Surati, S.Pd., Ibu Ni Ketut Ayu Ratmini, S.Pd., Ibu Anik Utariyani, S.Pd., dan Ibu Ni Komang Lantari, S.Pd beserta dengan Kepala Sekolah dan beberapa rekan guru sebagai informan pendukung yang dilakukan pada tanggal 3 Februari 2020 mengenai implementasi kebijakan program sertifikasi guru khususnya pada guru Pendidikan Pancasila dan Kewarganegaraan di SMP Negeri 2 Kuta Utara Kabupaten Badung secara umum di dapatkan informasi bahwa program kebijakan sertifikasi guru tersebut sejauh ini sudah berjalan dengan baik, karena guru sudah diberikan sertifikat sebagai bukti nyata yang menunjukan bahwa guru tersebut telah diakui profesionalitasnya yang diperoleh setelah dinyatakan lulus dari pendidikan dan pelatihan yang diadakan pemerintah.

Kebijakan program sertifikasi guru ini tentunya menimbulkan adanya hak dan kewajiban sesuai dengan apa yang telah diamanatkan oleh Undang-Undang dimana pemerintah akan memberikan suatu penghargaan berupa tunjangan profesi sebesar 1x gaji pokok kepada guru yang telah lulus program tersebut apabila dapat memenuhi dan melaksanakan tugas-tugas/kewajiban sesuai dengan aturan yang telah ditentukan. Untuk di SMP Negeri 2 Kuta Utara Kabupaten Badung, para guru khusus nya guru PPKn tidak mengalami kendala dalam pemenuhan beban mengajar selama 24 jam karena sekolah memperkenankan guru tersebut untuk mendapatkan tugas tambahan dengan merangkap jabatan, contoh untuk menjadi Kepala Lab ataupun Waka Urusan Bidang, yang kinerjanya diakui selama 12 jam.

Namun tidak semua guru yang diperlakukan seperti itu. Artinya memang hanya 
guru-guru yang dirasa punya keahlian dan kemampuan di bidang tertentu yang mendapat kesempatan untuk bisa merangkap jabatan. Kemudian berbicara mengenai sikap profesionalisme guru khususnya guru Pendidikan Pancasila dan Kewarganegaraan di SMP Negeri 2 Kuta Utara Kabupaten Badung, sesuai dengan apa yang dituturkan oleh Ibu Ni Ketut Sri Arini, S.Pd dan Ibu Anik Utariyani, S.Pd dirasa memang mengalami suatu progress yang baik dalam hal ini mengalami suatu peningkatan pasca adanya program sertifikasi guru ini. Salah satunya dibuktikan dengan adanya peningkatan kinerja guru. Dimana setelah sertifikasi guru menjadi lebih rajin, lebih disiplin, selalu meningkatkan kemampuan yang dimilikinya, dan selalu berusaha agar nilai yang diperoleh peserta didik dapat meningkat.

3.2.2 Kendala-Kendala Yang Dihadapi Guru Pendidikan Pancasila dan Kewarganegaraan Sehubungan Dengan Pelaksanaan Program Sertifikasi Guru Dalam Meningkatkan Profesionalisme Guru di SMP Negeri 2 Kuta Utara Kabupaten Badung.

Dari hasil wawancara yang dilaksanakan dengan guru-guru Pendidikan Pancasila dan Kewarganegaraan di SMP Negeri 2 Kuta Utara Kabupaten Badung, yakni dengan Ibu Ni Ketut Sri Arini, S.Pd., Ibu Ni Made Rai Surati, S.Pd., Ibu Ni Ketut Ayu Ratmini, S.Pd., Ibu Anik Utariyani, S.Pd., dan Ibu Ni Komang Lantari, S.Pd yang dilakukan pada tanggal 10 Februari 2020 mengenai kendalakendala yang dihadapi guru Pendidikan Pancasila dan Kewarganegaraan sehubungan dengan pelaksanaan program sertifikasi guru dalam meningkatkan profesionalisme guru di SMP Negeri 2 Kuta Utara secara umum di dapatkan informasi bahwa untuk di SMP Negeri 2 Kuta Utara, sejauh ini dirasakan tidak ada kendala yang berarti terutama mengenai masalah jam mengajar, dikarenakan keadaan siswa dan jumlah kelas yang ada di SMP Negeri 2 Kuta Utara Kabupaten Badung itu lumayan banyak/lebih dari cukup dimana hanya ada 5 (lima) orang guru yang bertugas untuk mengampu mata pelajaran PPKn di semua kelas yang ada, dimulai dari kelas VII, VIII, dan IX sehingga tidak perlu lagi untuk mencari jam tambahan mengajar keluar dari sekolah induk.

Akan tetapi terdapat kendala lain yang muncul yang juga dirasakan secara umum oleh guruguru lain di SMP Negeri 2 Kuta Utara Kabupaten Badung yakni penyediaan fasilitas/sarana prasarana pendidikan yang masih terbatas seperti LCD yang sedikit banyak berimplikasi terhadap pelaksanaan proses pembelajaran menjadi terbatas dan cenderung penyampaian materi bahan ajar dari guru belum berkembang dengan semestinya Kemudian adanya masalah terhadap administrasi penilaian siswa yang terdiri dari berbagai aspek sebagai implikasi dari penerapan kurikulum 2013. Namun kendala-kendala yang dihadapi tersebut, sudah dapat teratasi dengan cukup baik walaupun belum semaksimal mungkin.

3.2.3 Solusi Terhadap Permasalahan Yang Dihadapi Oleh Guru Pendidikan Pancasila dan Kewarganegaraan Sehubungan Dengan Pelaksaanan Program Sertifikasi Guru Dalam Meningkatkan Profesionalisme Guru di SMP Negeri 2 Kuta Utara Kabupaten Badung

Untuk mengatasi kendala-kendala yang dihadapi oleh guru Pendidikan Kewarganegaraan sehubungan dengan pelaksaanan kebijakan program sertifikasi guru terhadap profesionalisme guru di SMP Negeri 2 Kuta Utara Kabupaten Badung, sesuai wawancara yang telah di lakukan maka alternatif penyelesaiannya adalah dengan cara; 
1. Sekolah harus mengupayakan pemenuhan kebutuhan fasilitas pendidikan yang memadai dan relevan dengan tuntutan dan situasi pembelajaran terkini secara bertahap dan berkelanjutan, misalnya melalui perencanaan, pengeloalaan dan pemanfaatan dana yang tersedia secara bijaksana baik dari swadaya, subsidi pemerintah misalnya Bantuan Operasional Sekolah (BOS), Bantuan Operasional Pendidikaan (BOP), Block Grand Pendidikan, dan donasi pendidikan lainnya yang sejenis. Tentunya upaya tersebut juga membutuhkan sinergi antara guru dan siswa untuk saling mencari sumber-sumber belajar lain yang dapat membantu proses kegiatan belajar mengajar sembari menunggu upaya yang dilakukan pihak sekolah dapat terealisasi. Dengan demikian diharapkan proses kegiatan pembelajaran dapat berlangsung dengan efektif dan efisien sehingga tujuan pembelajaran yang dicanangkan dapat tercapai.

2. Sekolah dapat membantu guru yang kesulitan mengurus administrasi penilaian siswa dengan memberikan pelatihan yang lebih terhadap guru tersebut melalui penyediaan tenaga TI professional misalnya, sehingga lama-kelamaan guru tersebut dapat mengerjakan administrasi penilaian tersebut dengan mudah karena pemenuhan kompetensi profesionalisme dalam hal penggunaan dan penguasaan ICT sudah dikuasai.

3. Perlunya pengaturan jadwal pelaksanaan MGMP PPKn secara rutin, sehingga semua guru PPKn dapat mengikuti Musyawarah Guru Mata Pelajaran tersebut dan pelaksanaan MGMP PPKn yang sebelumnya 1 kali sebulan misalnya, sebaiknya dapat ditingkatkan intensitas pertemuannya menjadi 2 kali dalam sebulan. Hal ini bertujuan untuk peningkatan komunikasi yang efektif antar guru mata pelajaran PPKn untuk mendiskusikan dan menyelesaikan permasalahan-permasalahan yang dihadapi oleh guru dalam meningkatkan profesionalisme guru PPKn.

\section{SIMPULAN DAN SARAN}

4.1 Simpulan

Dari seluruh uraian di atas tentang Implementasi Program Sertifikasi Guru Dalam Meningkatkan Profesionalisme Guru (Studi Pada Guru Pendidikan Pancasila dan Kewarganegaraan Di SMP Negeri 2 Kuta Utara Kabupaten Badung), maka dapat dirumuskan beberapa simpulan, yakni sebagai berikut:

1. Program sertifikasi tersebut sudah terimplementasikan dengan baik dimana sertifikasi berpengaruh terhadap sikap profesionalisme guru Pendidikan Pancasila dan Kewarganegaraan di SMP Negeri 2 Kuta Utara Kabupaten Badung yang dibuktikan dengan adanya peningkatan kinerja guru dimana setelah sertifikasi guru menjadi lebih rajin, lebih disiplin, selalu meningkatkan kemampuan yang dimilikinya, serta selalu berusaha dengan segala cara agar nilai yang diperoleh peserta didik dapat meningkat.

2. Pelaksanaan program sertifikasi guru dalam meningkatkan profesionalisme guru di SMP Negeri 2 Kuta Utara Kabupaten Badung memang masih mengalami beberapa kendala yaitu penyediaan fasilitas pendidikan yang masih terbatas seperti LCD dan adanya masalah terhadap administrasi penilaian siswa sebagai implikasi dari penerapan kurikulum 2013. 
3. Untuk mengatasi kendala-kendala yang dihadapi oleh guru Pendidikan Kewarganegaraan sehubungan dengan pelaksaanan kebijakan program sertifikasi guru terhadap profesionalisme guru di SMP Negeri 2 Kuta Utara Kabupaten Badung, sesuai wawancara yang telah di lakukan maka alternatif penyelesaiannya adalah dengan cara; sekolah dapat mengupayakan pemenuhan kebutuhan fasilitas pendidikan yang memadai dan relevan dengan pembelajaran terkini secara bertahap melalui perencanaan, pengeloalaan dan pemanfaatan dana yang tersedia, baik dari swadaya atau subsidi pemerintah; penyediaan tenaga TI professional untuk memberikan pelatihan guna membantu guru yang masih kesulitan mengerjakan administrasi penilaian siswa karena kendala pengoprasian ICT; dan perlunya pengaturan intensitas pertemuan MGMP PPKn secara rutin, guna membangun komunikasi yang efektif antar guru mata pelajaran PPKn.

4.2 Saran

Dari simpulan diatas, dapat disarankan beberapa hal sebagai berikut :

1. Bagi Sekolah, Dari ketiga komponen baik siswa, guru maupun sekolah harus saling mendukung kebijakan sertifikasi guru. Dari siswa sebaiknya lebih aktif dalam mempersiapkan dan mencari sumber belajar sendiri begitu juga dalam proses belajar mengajar. Dari guru sebaiknya mampu untuk menghadapi tantangan global untuk lebih meningkatkan kompetensi dan profesionalisme guru dimana guru PPKn nantinya dapat saling bekerja sama dengan guru mata pelajaran lain terutama dalam mengembangkan media pembelajaran agar mempermudah guru PPKn dalam proses mengajar. Untuk sekolah sebaiknya menyediakan sarana dan prasarana yang dapat mendukung berjalannya sertifikasi guru guna mewujudkan lingkungan belajar yang kondusif. Selain itu pimpinan sekolah juga perlu untuk selalu mengontrol serta mengevaluasi guru maupun siswa untuk mendukung keberhasilan kebijakan sertifikasi guru.

\section{DAFTAR PUSTAKA}

Arikunto, Suharsimi. 2007, Prosedur Penelitian, Suatu Pendekatan Praktek (ed. Revisi v). Jakarta: Rineka CiptaBali). Sekolah Pascasarjana UPI: Bandung.

Asmani, JM. 2009, Tips Menjadi Guru Inspiratif, Kreatif, \& Inovatif. Yogyakarta: Diva Press.

Danim, Sudarwan. 2010, Profesionalisasi dan Etika Profesi Guru. Cet. kesatu: Bandung: Alfabeta.

Djaali. 2009. Peningkatan Mutu Pendidikan Nasional Melalui Program Sertifikasi.

Kunandar. 2009, Guru Profesional Imlpementasi KTSP dan Sukses dalam Sertifikasi, Jakarta: Raja Grafindo Persada.

Milles, Matthew B dan A. Michael Huberman. 2007. Analisis Data Kualitatif. Jakarta : Penerbit Universitas Indonesia

Moelong, Lexy J. 2006. Metodologi Penelitian Kualitatif. Bandung: PT. Remaja Rosdakarya Offsed

Mulyasa, E. 2012, Standar Kompetensi dan Sertifikasi Guru. Cet. Keenam; Jakarta : PT. Remaja Rosdakarya.

Peraturan Pemerintah Republik Indonesia Nomor 19 Tahun 2005 Tentang Standar Nasional Pendidikan. Cet. keempat; Jakarta: Sinar Grafika.

Peraturan Menteri Pendidikan Nasional Republik Indonesia Nomor 11 tahun 2011 tentang Sertifikasi Bagi Guru dalam Jabatan.

Peraturan Menteri Pendidikan Nasional Nomor 16 tahun 2007 tentang Standar Kualifikasi Akademik dan Kompetensi Guru.

Ruky, Ahmad S, 2002, Sistem Menajemen Kinerja. Cet. II: Jakarta: PT. Gramedia Pustaka Utama.

Santika, I Gusti Ngurah dan Kartika, I Made. Pendidikan Karakter: Studi Kasus Peranan Keluarga Terhadap Pembentukan Karakter 
Anak Ibu Sunah Di Tanjung Benoa. Jurnal Kajian Pendidikan Widya Accarya FKIP Universitas DwijendraISSN NO. 2085-0018 Maret 2019.

Saud, Udin Saefuddin, 2010, Pengembangan Profesi Guru. Cet. Ketiga ; Bandung: Alfabeta.

Undang-Undang RI No. 20 TH. 2003, tentang SISDIKNAS (Sistem Pendidikan Nasional). Cet. I; Jakarta: Sinar Grafika.

Undang-Undang RI No. 14 Th. 2005 Tentang Guru dan Dosen, Jakarta: Sinar Grafika.

Triyanto dan Titiki. 2007, Sertifikasi Guru dan Upaya Peningkatan Kualifikasi Kompetensi dan Kesejahteraan. Jakarta: Prestasi Pustaka.

Wibowo. 2006, Menajemen Kinerja. Jakarta: Raja Grafindo Persada. 